\title{
Trimethylamine oxide and derived compounds' changes during frozen storage of hake (Merluccius merluccius)
}

C. G. Sotelo, J. M. Gallardo, C. Piñeiro \& R. Perez-Martin

Instituto de Investigaciones Marinas (C.S.I.C.), Eduardo Cabello 6, 36208 Vigo, Spain

Changes in total volatile bases (TVB), dimethylamine (DMA), formaldehyde (FA), trimethylamine (TMA) and trimethylamine oxide (TMAO) of whole hake (Merluccius merluccius L.) were evaluated at different temperatures of storage: $-5,-12$ and $-20^{\circ} \mathrm{C}$. Significant changes in TVB, DMA, TMA, TMAO nitrogen and FA were observed at $5^{\circ} \mathrm{C}$. Only TMAO changed significantly at $-12^{\circ} \mathrm{C}$ and $-20^{\circ} \mathrm{C}$. TMAO decrease was not, therefore, followed by DMA and/or TMA production at those temperatures.

\section{INTRODUCTION}

Different studies have shown that dimethylamine (DMA), formaldehyde (FA) and trimethylamine (TMA) in fishery products originate by the breakdown of trimethylamine oxide (TMAO) (Castell et al. 1970). During frozen storage, DMA and FA are the result of the TMAO decomposition catalysed by an endogenous enzyme present in certain gadoid species (Yamada et al., 1969; Castell et al., 1973). The enzyme responsible for this reaction consists of two possible protein fractions and co-factor (Harada, 1975). Oxygen or potential oxidants, such as oxidised lipids, have been reported to be inhibitors of TMAOase (Lundstrom et al., 1982; Reece, 1983; Careche \& Tejada, 1990).

Quality changes of frozen gadoids might be estimated by chemical indices such as total volatile base nitrogen (TVB-N) and DMA. Production of DMA depends on subzero temperature of storage, being maximal at $-5^{\circ} \mathrm{C}$ (Caste11 et al., 1973). It is presumed that any production of DMA and TMA comes from degradation of TMAO and, any degradation of TMAO is reflected by an increase in DMA and/or TMA. However, previous reports have shown that, under certain conditions, TMAO is degraded faster than the production of DMA and/or TMA. These conditions consisted of an inhibition of the enzyme by the presence of oxygen (Lundstrom et al., 1981; Reece, 1983; Racicot et al., 1984). 
Differences of subzero temperatures of storage produce differences in degree of activity of the enzyme. Therefore a study of the TMAO and derived compounds was undertaken to follow any relationship between production of DMA and/or TMA and TMAO decrease in the muscle of whole frozen hake (Merluccius merluccius L.) stored at -5, 12 and $-20^{\circ} \mathrm{C}$.

\section{MATERIALS AND METHODS}

Fish samples

Hake (Merluccius merluccius L.), of 0.5-0.8 kg, were obtained $24 \mathrm{~h}$ after catching from a fish local market. The fish were eviscerated when landed and each individual was measured and weighed. The whole body of every individual was immediately blastfrozen until it reached the temperature of $-40^{\circ} \mathrm{C}(2 \mathrm{~h})$. Each frozen fish was packed in a polyethylene bag and randomly divided into three batches, each of them stored at $-5,-12$ and $-20^{\circ} \mathrm{C}$. At defined intervals, individuals (1-3) were removed from frozen storage, thawed ( $4^{\circ} \mathrm{C}$ overnight) and prepared for analysis by deboning and mincing the flesh.

TVB-N

TVB-N was obtained by steam distillation during $10 \mathrm{~min}$ of $10 \mathrm{~g}$ of minced flesh with 2 g $\mathrm{MgO}$ and $30 \mathrm{ml}$ of distilled water. Distillate was titrated with $10 \mathrm{mM}$ hydrochloric acid (Lucke \& Geidel, 1935).

DMA, TMA and TMAO determination

Extracts of each fish were prepared by blending $20 \mathrm{~g}$ of the minced flesh with $60 \mathrm{ml}$ of an aqueous solution of 5\% (w/v) trichloroacetic acid (TCA) for 2 min in an Ultra Turrax macerator. The extracts were allowed to stand for $15 \mathrm{~min}$ at $4^{\circ} \mathrm{C}$, stirred and filtered through a filter paper in order to obtain a clear extract. Extracts were made up to $100 \mathrm{ml}$ with 5\% TCA solution and kept frozen until analysis. 
DMA and TMA was measured by the spectrophotometric method described by Tozawa et al. (1970), and TMAO by reduction with titanium (III) chloride (Parkin \& Hultin, 1982) and analysis of TMA formed by the spectrophotometric method.

FA extract preparation and measurement

FA was determined by the spectrophotometric method of Nash (1953) in an aqueous extract of the muscle. This extract was obtained by steam distillation of presence of the muscle in the 85\% phosphoric acid (Rehbein, 1987).

Statistical analysis

Linear regression analyses of changes of TVB-N, DMA-N, TMA-N, TMAO-N and free FA versus time of storage were done with the data obtained from one up to three individuals per period and temperature.

\section{RESULTS AND DISCUSSION}

Figure 1 shows the evolution of TVB-N of muscle of hake stored at $-5,-12$ and $-20^{\circ} \mathrm{C}$. Initial contents of muscle (unfrozen individuals) were quite low (mean $=18.5 \mathrm{mg}$ TVBN/100 g, $\mathrm{SE}=0,688, \mathrm{n}=3$ ). Higher values were described by Almandos et al. (1984) for minced and filleted Merluccius hubbsi (32 and $26 \mathrm{mg}$ TVB-N/100 g, respectively); however, similar values were described by Perez-Villarreal and Howgate (1987) (15 mg of TVB-N/100 g) working with whole European hake (Merluccius merluccius). Significant change in TVB-N was $0.225 \mathrm{mg}$ per day when storing at $-5^{\circ} \mathrm{C}$ while at $12^{\circ} \mathrm{C}$ the increase was $0.031 \mathrm{mg}$ per day.

Changes in DMA-N are presented in Fig. 2. Initial values were 068 mg DMA-N/100 g. Again, the values were lower than others previously reported. This might be due to degree of manipulation. Fish, filleted or minced, present higher values of DMA or TVB-N, because of distribution of the enzyme (TMAOase) throughout the muscle (Mackie \& Thompson, 1974). DMA-N showed significant changes at $-5^{\circ} \mathrm{C}(\mathrm{P}<0.01)$ but no changes could be observed by regression analysis at -12 and $-20^{\circ} \mathrm{C}$. PerezVillarreal and Howgate (1991) found DMA content predictor of storage time of fillets 
but not of whole fish. When comparing slopes of regression lines belonging to DMA-N and TVB-N, the slopes were significantly different $(\mathrm{P}<0.05)$; this means that DMA is contributing to TVB formation but it is not the only source. Some authors (Almandos et al., 1984) discussed that this increment is only due to DMA but the current results show that other factors, such as production of $\mathrm{NH}$, by amino acid deamination, might be involved, because slopes are statistically different.

FA is produced during the storage at $-5^{\circ} \mathrm{C}(\mathrm{P}<0.01)$. Also at -12 and $-20^{\circ} \mathrm{C}$ there appeared to be significant regression lines for FA production although slopes were rather small, indicating that increase during storage is small (Fig. 3). In the same way as TVB-N and DMA-N production rate are dependent on storage temperature. FA slopes are smaller at lower storage temperatures.

Trimethylamine was also measured in our experiment. The low initial content $($ mean $=$ $0.41 \mathrm{mg}$ TMA-N/100 $\mathrm{g}, \mathrm{SE}=0.010, \mathrm{n}=2$ ) in this amine was indicative of fish of excellent quality, grade I, which correspond to values between 0 and 1 mg TMA-N/100 g (Caste11 et al., 1958). Reported values of this species were similar (Rehbein, 1988). TMA is due to the activity of bacterial enzymatic decomposition of TMAO (Pedrosa-Menabrito \& Regenstein, 1988). Therefore, changes in TMA-N were not expected during frozen storage. As can be observed in Fig. 4, little change occurred at $5^{\circ} \mathrm{C}$ and none at -12 and $-20^{\circ} \mathrm{C}$. Although it has been said that bacterial growth is inhibited at temperatures below $0^{\circ} \mathrm{C}$ (Castell et al., 1973) some growth had been observed at temperatures of $65^{\circ} \mathrm{C}$ (Reay \& Shewan, 1949). Also, LeBlanc et al. (1988) and Rehbein (1988) found changes in TMA-N during storage of cod (Gadus morhua) and hake (Merluccius mer1uccius) at -12 and $-8^{\circ} \mathrm{C}$ respectively. At lower temperatures of storage, no changes were described (Babbitt et al., 1972; Mackie \& Thompson, 1974).

TMAO-N initial content was $27.9 \mathrm{mg} / 100 \mathrm{~g}$. TMAO content was found very variable in different species of fish and also in hake, values ranging from $10.9 \mathrm{mg}$ TMAON/100 g to 86.5 mg TMAO-N/100 g (Rehbein, 1988).

TMAO degradation followed very similar patterns in the muscle of hake regardless of temperature of storage $\left(-5,-12\right.$ and $\left.-20^{\circ} \mathrm{C}\right)$. Figure 5 shows regression analyses at three 
temperatures of storage. In each case a negative and significant slope was obtained indicative of a degradation kinetic. However, only in those cases where increase in DMA and/or TMA were observed would a degradation of TMAO be expected. DMA and TMA are both produced at $-5^{\circ} \mathrm{C}$; at $-12^{\circ} \mathrm{C}$ there is a small increase of DMA and none of TMA, while at $-20^{\circ} \mathrm{C}$ none of the amines is produced. In these three cases TMAO is decreasing at almost the same rate (slope of regression lines).

If the three related compounds DMA-N, TMA-N and TMAO-N are pooled and regression analysis is performed versus time of storage, the sum only remains balanced when hake is stored at $-5^{\circ} \mathrm{C}$. The sum decreases significantly at -12 and $-20^{\circ} \mathrm{C}(\mathrm{P}<$ 0.01) (Fig. 6). TMAO degradation was expected in those cases where a production of either TMA and/or DMA took place, but it was not when both compounds did not vary with storage time. In our experiment, TMA-N or DMA-N did not show significant changes at $-12^{\circ} \mathrm{C}$ and $-20^{\circ} \mathrm{C}$. Lundstrom et al. (1981) found that red hake (Urophycis chum) fillets when exposed to air and stored on ice lost TMAO-N at a higher rate than DMA or TMA production rate. In the same way, TMAO decrease was not accompanied by DMA production when TMAOase was inhibited by the presence of oxygen (Banda \& Hultin, 1983; Reece 1983, 1985; Racicot et al., 1984). Reece (1983) has suggested that, either TMAO is degraded by alternative unknown pathways, or TMA and DMA are further degraded to other compounds, becoming non-detectable by present methods. The results presented here show that, when low temperatures of storage are employed, TMAO could be degraded; however, no changes in the established chemical indices take place. This suggests other processes which could take place in frozen stored fish muscle whose importance might be neglected.

\section{ACKNOWLEDGEMENT}

The authors wish to thank CICYT for the financial support of the project 608/516 AL1 88-0145CO2-02.

\section{REFERENCES}


Almandos, M. E., Giannini, D. H., Ciarlo, A. S. \& Boeri, R. L. (1984). Relationship between the increase of total volatile bases and dimethylamine in frozen patagonian hake (Merluccius hubbsi). Lebensm. Wiss. Technol., 17, 111-13.

Babbitt, J. K., Crawford, D. L. \& Law, D. K. (1972). Decomposition of trimethylamine oxide and changes in protein extractability during frozen storage of minced and intact hake (Merluccius productus) muscle. J. Agric. Food Chem., 20(5), 1052-4.

Banda, M. C. M. \& Huhin, H. 0. (1983). Role of cofactors in breakdown of TMAO in frozen red hake muscle. J. Food Process. Preserv., 7, 221-36.

Careche, M. \& Tejada, M. (1990). The effect of neutral and oxidized lipids on functionality in hake (Merluccius merluccius L.): A dimethylamine - and formaldehyde - forming species during frozen storage. Food Chem., 36, 113-28.

Castell, C. H., Greenough, M. F., Rodgers, R. S. \& Macfarland, A. S. (1958). Grading fish for quality. Y. Trimethylamine values of fillets cut from graded fish. J. Fish. Res. Board Can., 15, 701-16.

Castell, C. H., Neal, W. \& Smith, B. (1970). Formation of dimethylamine in stored frozen sea fish. J. Fish. Rex Board Can., 27, 1685-90.

Castell, C. H., Neal, W. E. \& Dale, J. (1973). Comparison of changes in trimethylamine, dimethylamine and extractable protein in iced and frozen gadoid fillet. J. Fish. Res. Board Can., 30, 1246-8.

Harada, K. (1975). Studies on the enzyme catalyzing the formation of formaldehyde and dimethylamine in tissues of fishes and shells. J. Shimonoseki Univ. Fish. 23, 163241.

LeBlanc, E. L., LeBlanc, R. J. \& Blum, I. E. (1988). Prediction of quality in frozen cod (Gadus morhua) fillets. J. Food Sci. 53(2), 328-39.

Lucke, F. \& Geidel, W. (1935). Bestimmung des fluchtigen basischen Stickstoffs in Fischen als Masstab fur ihren Frischezustand. 2. Lebens. Unters. Forsch., 70, 44158.

Lundstrom, R. C., Correia, F. F. \& Wilhelm, K. A. (1981). Dimethylamine and formaldehyde production in fresh red hake (Urophycis chuss) the effect of packaging material oxygen permeability and cellular damage. Z.I. F.-H. R. Comm. C-2, D-1, D-2, D-3, Boston, 457-64.

Lundstrom, R. C., Correia, F. F. \& Wilhelm, K. A. (1982). Enzymatic dimethylamine and formaldehyde production in minced american plaice and blackback flounder mixed with a red hake TMAO-ase active fraction. J. Food Sci. 47, 1305-10. 
Mackie, I. M. \& Thompson, B. W. (1974). Decomposition of trimethylamine oxide during iced and frozen-storage of whole and comminuted tissue of fish. Proc. IV Int. Congress Food Sci. Technol., 1, 243-50.

Nash, T. (1953). The calorimetric estimation of formaldehyde by means of the Hantzsch reaction. Biochem. J., 55, 416-21.

Parkin, K. L. \& Hultin, H. 0. (1982). Some facts influencing the production of dimethylamine and formaldehyde in minced and intact red hake muscle. J. Food Proc. Preserv., 6, 73-97.

Pedrosa-Menabrito, A. \& Regenstein, J. M. (1988). Shelf-life extension of fresh fish - a review. Part 1 - Spoilage of fish. J. Food Quality, 11, 117.

Perez-Villarreal, B. \& Howgate, P. (1987). Composition of European hake (Merluccius merluccius). J. Sci. Food Agric., 40, 347-56.

Perez-Villarreal, B. \& Howgate, P. (1991). Deterioration of European hake (Merluccius merluccius) during frozen storage. J. Sci. Food Agric., 55, 455-69.

Racicot, L. D., Lundstrom, R. C., Wilhelm, K. A., Ravesi, E. M. \& Licciardello, J. J. (1984). Effect of oxidizing and reducing agents on trimethylamine $\mathrm{N}$-oxide demethylase activity in red hake muscle. J. Agric. Food Chem., 32, 459-64.

Reay, G. A. \& Shewan, J. M. (1949). The spoilage of fish and its preservation by chilling. Adv. Food Res., 2, 343.

Reece, P. (1983). The role of oxygen in the production of formaldehyde in frozen minced cod muscle. J. Sci. Food Agric., 34, 1108-12.

Reece, P. (1985). The fate of reduced nicotinamide adenine dinucleotide in minced flesh of cod (Gadus morhua) and its association with formaldehyde production during frozen storage. I.I.F.-I.I.R. Comm. C2 and C3, 319-323.

Rehbein, H. (1987). Determination of the formaldehyde content in fishery products. Z. Lebensm. Unters Forsch., 185, 292-8.

Rehbein, H. (1988). Relevance of trimethylamine oxide demethylase activity and haemoglobin content to formaldehyde production and texture deterioration in frozen stored minced fish muscle. J. Sci. Food Agric., 43, 261-76.

Tozawa, H., Erokibara, K. \& Amano, K. (1970). Effect of dimethylamine on the value of trimethylamine determined by the Dyer’s method. Bull. Jap. Soc. Sci. Fish., 36, 606. 
Yamada, K., Harada, K. \& Amano, K. (1969). Biological formation of formaldehyde and dimethylamine in fish and shellfish. VIII. Requirement of cofactor in the enzyme system. Bull. Jap. Sot. Sci. Fish., 31, 1030. 
Fig. 1. TVB-N content of hake muscle stored at $-5,-12$ and $-20^{\circ} \mathrm{C}$ during the period of time of study. Regression lines were plotted in each case; equations, coefficients $\left(\mathrm{r}^{2}\right)$, significance and number of individuals analysed (n) were as follows:

$-5^{\circ} \mathrm{C}: \mathrm{y}=0.225 \mathrm{x}+8.17, \mathrm{r}^{2}=0.92(\mathrm{P}<0.01), \mathrm{n}=22$.

$-12^{\circ} \mathrm{C}: \mathrm{y}=0.031 \mathrm{x}+18.98, \mathrm{r}^{2}=044(\mathrm{P}<0.01), \mathrm{n}=18$.

$-20^{\circ} \mathrm{C}: \mathrm{y}=0.013 \mathrm{x}+18.13, \mathrm{r}^{2}=0.13(\mathrm{P}>0.05), \mathrm{n}=15$.

Fig. 2. DMA-N content of hake muscle stored at $-5,-12$ and $-20^{\circ} \mathrm{C}$ during the period of time of study. Regression lines were plotted in each case; equations, coefficients $\left(\mathrm{r}^{2}\right)$, significance and number of individuals analysed (n), were as follows:

$-5^{\circ} \mathrm{C}: \mathrm{y}=0.121 \mathrm{x}-0.162, \mathrm{r}^{2}=0.87(\mathrm{P}<0.01), \mathrm{n}=11$.

$-12^{\circ} \mathrm{C}: \mathrm{y}=0.05 \mathrm{x}+1.592, \mathrm{r}^{2}=0.091(\mathrm{P}>0.05), \mathrm{n}=13$.

$-20^{\circ} \mathrm{C}: \mathrm{y}=0.02 \mathrm{x}+0.846, \mathrm{r}^{2}=0.042(\mathrm{P}>0.05), \mathrm{n}=12$.

Fig. 3. FA content of hake muscle stored at $-5,-12$ and $-20^{\circ} \mathrm{C}$ during the period of time of study. Regression lines were plotted in each case; equations, coefficients $\left(\mathrm{r}^{2}\right)$. significance and number of individuals analysed (n) were as follows:

$-5^{\circ} \mathrm{C}: \mathrm{y}=064 \mathrm{x}+8.387, \mathrm{r}^{2}=0.80(\mathrm{P}<0.01), \mathrm{n}=22$.

$-12^{\circ} \mathrm{C}: \mathrm{y}=0.152 \mathrm{x}+7.043, \mathrm{r}^{2}=0.543(\mathrm{P}<0.01, \mathrm{n}=18$.

$-20^{\circ} \mathrm{C}: \mathrm{y}=0.041 \mathrm{x}+3.178, \mathrm{r}^{2}=0.354(\mathrm{P}<0.05), \mathrm{n}=15$.

Fig. 4. TMA content of hake muscle stored at $-5,-12$ and $-20^{\circ} \mathrm{C}$ during the period of time of study. Regression lines were plotted in each case; equations, coefficients $\left(\mathrm{r}^{2}\right)$, significance and number of individuals analysed (n) were as follows:

$-5^{\circ} \mathrm{C}: \mathrm{y}=0.019 \mathrm{x}+0.288, \mathrm{r}^{2}=0.755(\mathrm{P}<0.01), \mathrm{n}=12$.

$-12^{\circ} \mathrm{C}: \mathrm{y}=0,001 \mathrm{x}+0.565, \mathrm{r}^{2}=0.071(\mathrm{P}>0.05), \mathrm{n}=13$.

$-20^{\circ} \mathrm{C}: \mathrm{y}=0.005 \mathrm{x}+0.425, \mathrm{r}^{2}=0.110(\mathrm{P}>0.05), \mathrm{n}=12$.

Fig. 5. TMAO-N content of hake muscle stored at $-5,-12$ and $-20^{\circ} \mathrm{C}$ during the period of time of study. Regression lines were plotted in each case; equations, coefficients $\left(\mathrm{r}^{2}\right)$, significance and number of individuals analysed (n) were as follows:

$-5^{\circ} \mathrm{C}: \mathrm{y}=4.106 \mathrm{x}+24.194, \mathrm{r}^{2}=0.578(\mathrm{P}<0.01), \mathrm{n}=11$.

$-12^{\circ} \mathrm{C}: \mathrm{y}=4.122 \mathrm{x}+30.723, \mathrm{r}^{2}=0.646(\mathrm{P}<0.01), \mathrm{n}=13$.

$-20^{\circ} \mathrm{C}: \mathrm{y}=0.110 \mathrm{x}+28.388, \mathrm{r}^{2}=0.369(\mathrm{P}<0.05), \mathrm{n}=12$. 
Fig. 6. Sum of TMAO-N, DMA-N and TMA-N contents of hake muscle stored at -5, 12 and $-20^{\circ} \mathrm{C}$ during the period of time of study. Regression lines were plotted in each case; equations, coefficients $\left(\mathrm{r}^{2}\right)$, significance and number of individuals analysed (n) were as follows:

$-5^{\circ} \mathrm{C}: \mathrm{y}=0.034 \sim+24.327, \mathrm{r}^{2}=0.057(\mathrm{P}>0.05), \mathrm{n}=11$.

$-12^{\prime} \mathrm{C}: \mathrm{y}=-0.118,+33.180, \mathrm{r}^{2}=0.567(\mathrm{P}<0.01), \mathrm{n}=13$.

$-20^{\circ} \mathrm{C}: \mathrm{y}=0.104 . \mathrm{x}+29857, \mathrm{r}^{2}=0.314(\mathrm{P}<0.01), \mathrm{n}=12$. 